\title{
Raman Micro Spectroscopy for In Vitro Drug Screening: Subcellular Localisation and Interactions of Doxorubicin
}

\author{
Zeineb Farhane \\ Technological University Dublin \\ Franck Bonnier \\ Technological University Dublin, Franck.Bonnier@tudublin.ie \\ Alan Casey \\ Technological University Dublin, alan.casey@tudublin.ie
}

See next page for additional authors

Follow this and additional works at: https://arrow.tudublin.ie/biophonart

Part of the Analytical, Diagnostic and Therapeutic Techniques and Equipment Commons, Pharmaceutical Preparations Commons, and the Physics Commons

\section{Recommended Citation}

"Raman micro spectroscopy for in vitro drug screening: subcellular localisation and interactions of Doxorubicin, Z. Farhane, F. Bonnier, A. Casey and H.J. Byrne, Analyst, 140, 4212-4223 (2015) DOI: $10.1039 / \mathrm{c5an00256g}$

This Article is brought to you for free and open access by the DIT Biophotonics and Imaging at ARROW@TU Dublin. It has been accepted for inclusion in Articles by an authorized administrator of ARROW@TU Dublin. For more information, please contact arrow.admin@tudublin.ie, aisling.coyne@tudublin.ie,gerard.connolly@tudublin.ie. Funder: SFI

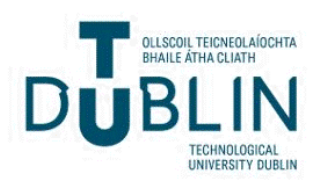




\section{Authors}

Zeineb Farhane, Franck Bonnier, Alan Casey, and Hugh Byrne

This article is available at ARROW@TU Dublin: https://arrow.tudublin.ie/biophonart/18 
1

\section{Raman micro spectroscopy for in vitro drug screening: subcellular localisation and interactions of doxorubicin}

Z. Farhane,* F. Bonnier, A. Casey and H. J. Byrne

Raman spectroscopy is used for the localization and tracking of chemotherapeutic drug, doxorubicin, in the intracellular environment of lung cancer cell line. Results show the potential of the technique to monitor the mechanisms of action and response on a molecular level, with subcellular resolution.

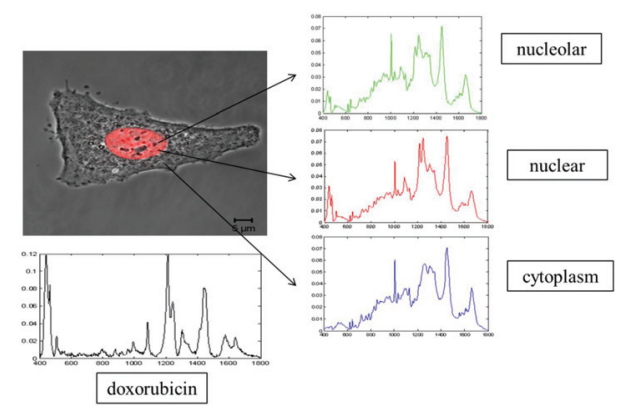

Please check this proof carefully. Our staff will not read it in detail after you have returned it.

Translation errors between word-processor files and typesetting systems can occur so the whole proof needs to be read. Please pay particular attention to: tabulated material; equations; numerical data; figures and graphics; and references. If you have not already indicated the corresponding author(s) please mark their name(s) with an asterisk. Please e-mail a list of corrections or the PDF with electronic notes attached - do not change the text within the PDF file or send a revised manuscript. Corrections at this stage should be minor and not involve extensive changes. All corrections must be sent at the same time.

Please bear in mind that minor layout improvements, e.g. in line breaking, table widths and graphic placement, are routinely applied to the final version.

We will publish articles on the web as soon as possible after receiving your corrections; no late corrections will be made.

Please return your final corrections, where possible within $\mathbf{4 8}$ hours of receipt, by e-mail to: analyst@rsc.org 


\section{Queries for the attention of the authors}

Journal: Analyst

Paper: c5an00256g

Title: Raman micro spectroscopy for in vitro drug screening: subcellular localisation and interactions of doxorubicin

Editor's queries are marked like this [Q1, Q2,...], and for your convenience line numbers are indicated like this $[5,10,15, \ldots]$.

Please ensure that all queries are answered when returning your proof corrections so that publication of your article is not delayed.

\begin{tabular}{|l|l|l|}
\hline $\begin{array}{l}\text { Query } \\
\text { Reference }\end{array}$ & Query & Remarks \\
\hline Q1 & $\begin{array}{l}\text { For your information: You can cite this article before you } \\
\text { receive notification of the page numbers by using the following } \\
\text { format: (authors), Analyst, (year), DOI: } 10.1039 / c 5 a n 00256 \mathrm{~g} .\end{array}$ & \\
\hline Q2 & $\begin{array}{l}\text { Please carefully check the spelling of all author names. This is } \\
\text { important for the correct indexing and future citation of your } \\
\text { article. No late corrections can be made. }\end{array}$ & \\
\hline Q3 & Ref. 1, 14 and 51: Please provide the page (or article) number(s). & \\
\hline
\end{tabular}




\title{
Raman micro spectroscopy for in vitro drug screening: subcellular localisation and interactions of doxorubicin
}

\author{
Z. Farhane, ${ }^{\star a}{ }^{a}$ F. Bonnier, ${ }^{b}$ A. Casey ${ }^{a}$ and H. J. Byrne ${ }^{a}$
}

Vibrational spectroscopy, including Raman spectroscopy, has been widely used over the last few years to explore potential biomedical applications. Indeed, Raman spectroscopy has been demonstrated to be a powerful non-invasive tool in cancer diagnosis and monitoring. In confocal microscopic mode, the technique is also a molecularly specific analytical tool with optical resolution which has potential applications in subcellular analysis of biochemical processes, and therefore as an in vitro screening tool of the efficacy and mode of action of, for example, chemotherapeutic agents. In order to demonstrate and explore the potential in this field, established, model chemotherapeutic agents can be valuable. In study paper, Raman spectroscopy coupled with confocal microscopy were used for the localization and tracking of the commercially available drug, doxorubicin (DOX), in the intracellular environment of the lung cancer cell line, A549. Cytotoxicity assays were employed to establish clinically relevant drug doses for $24 \mathrm{~h}$ exposure, and confocal laser scanning fluorescence microscopy was conducted in parallel with Raman spectroscopy profiling to confirm the drug internalisation and localisation. Multivariate statistical analysis, consisting of PCA (principal components analysis) was used to highlight doxorubicin interaction with cancer cells and spectral variations due to its effects before and after DOX spectral features subtraction from nuclear and nucleolar spectra, were compared to non-exposed control spectra. Results show that Raman micro spectroscopy is not only able to detect doxorubicin inside cells and profile its specific subcellular localisation, but, it is also capable of elucidating the local biomolecular changes elicited by the

Received 5th February 2015, Accepted 31st March 2015

DOI: $10.1039 / \mathrm{c} 5 \mathrm{an} 00256 \mathrm{~g}$

www.rsc.org/analyst drug, differentiating the responses in different sub cellular regions. Further analysis clearly demonstrates the early apoptotic effect in the nuclear regions and the initial responses of cells to this death process, demonstrating the potential of the technique to monitor the mechanisms of action and response on a molecular level, with subcellular resolution.

\section{Introduction}

Although the potential of vibrational spectroscopy, including infrared absorption and Raman spectroscopy, for biomedical applications has been well demonstrated, translation to the clinical environment has been slow, potentially due to the demands of standardisation, regulation and extensive clinical trials. ${ }^{1,2}$ Fundamentally, the techniques are analytical, with molecular specificity, and, in the case of Raman spectroscopy in the confocal microscopy mode, can achieve optical resolution enabling subcellular profiling in $3 \mathrm{D}$, suggesting that an appropriate application would be in screening of biomolecular

${ }^{a}$ FOCAS Research Institute, Dublin Institute of Technology, Kevin Street, Dublin 8, Ireland

${ }^{b}$ Université François-Rabelais de Tours, Faculty of Pharmacy, EA 6295

Nanomédicaments et Nanosondes, 31 avenue Monge, 37200 Tours, France.

E-mail: zeineb.farhane@mydit.ie changes in vitro. ${ }^{3-6}$ Regulatory requirements in both the EU and US (EU Directive-2010/63/EU and US Public Law 106-545, $2010,106^{\text {th }}$ Congress) have increasingly restricted the use of animal models for development of pharmaceuticals and cosmetics, and Raman micro spectroscopy offers a potentially low cost, label free alternative to in vitro High Content Analysis for routine screening. ${ }^{7,8}$

The potential of Raman micro spectroscopy in this field has previously been demonstrated in a number of studies. ${ }^{9,10}$ The use of model systems, with established modes of action is of particular benefit in this respect, and commercially available drugs such as cisplatin (an alkylating and DNA binding agent) ${ }^{11,12}$ and vincristine (an alkaloid agent) ${ }^{13}$ have been explored. In these specific studies, however, the drug itself was not detected, but rather the spectroscopic response profiles of the cells themselves were correlated with the cytotoxic responses measured in cells. Nawaz et al., postulated that the direct chemical interaction of the drug in the cell could be 
A.

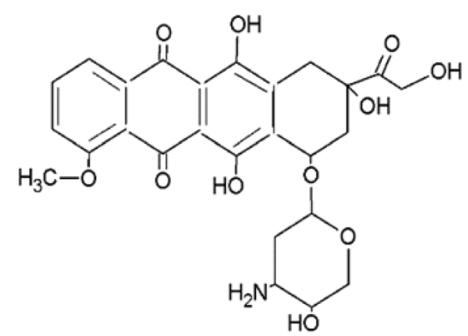

B.

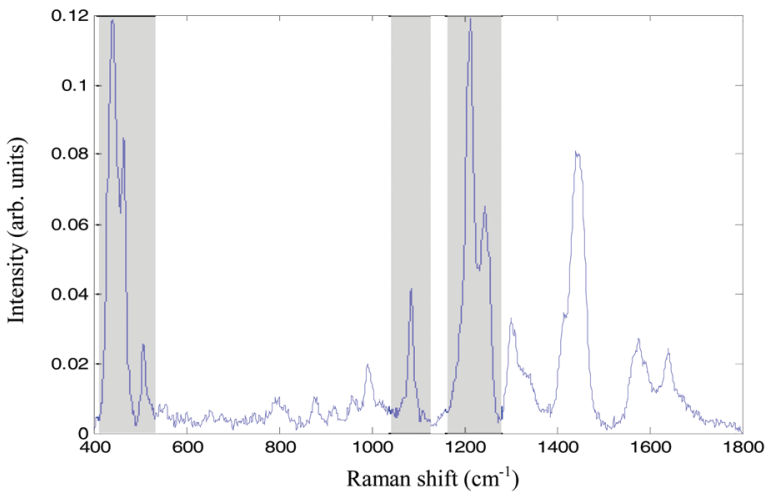
vector-normalised and baseline corrected).

differentiated from the resultant cytological response using multivariate regression, and this approach was recently validated by Keating et al. ${ }^{14}$ El-Mashtoly et al. ${ }^{15}$ utilised the distinct structure of Erlotinib, containing a carbon-carbon triple bond, to specifically detect the subcellular presence of the drug in vitro, while Cuisinier et al. used the $\mathrm{C}=\mathrm{O}$ stretching band at $1740 \mathrm{~cm}^{-1}$ to monitor paclitaxel (a microtubule stabilizing agent) in cells and Vigny et al. ${ }^{16}$ probed the resonance Raman response to detect and study nonfluorescent transition-metal complexes, Theraphtal, used as a chemotherapeutical combination. Raman spectroscopy has also been demonstrated as a suitable probe of subcellular localisation ${ }^{17-19}$ and toxicity of nanoparticles..$^{20-22}$

One of the 10 most frequent drugs used in cancer chemotherapy and especially for the treatment of aggressive and metastatic tumours is doxorubicin. ${ }^{23}$ Doxorubicin (DOX) is an anthracycline antibiotic extract from Streptomyces peucetius and a well-established anti-cancer drug (since 1960). ${ }^{24}$ It is widely used in chemotherapy for a varied range of cancers including breast carcinoma, haematological malignancies and lung cancer. Despite its known cardiotoxicity, it is currently one of the anticancer drugs most used in clinics. ${ }^{25,26}$ When taken up into cell nucleus, where it has high affinity for DNA and blocks topoisomerase $\mathrm{II}^{24,27}$ DOX induces genotoxicity and inhibits the process of DNA replication and macromolecular biosynthesis, leading to tumour cell apoptosis. ${ }^{28}$ As this interaction is dependent on the level of protein, cells with high levels of topoisomerase II are more susceptible to DOX, which explains its selectivity to cancer cells. ${ }^{24}$ In addition to the formation of complex drug-DNA-topoisomerase II, DOX also induces the formation of DNA adducts, ${ }^{25,29}$ hydrogen peroxide $^{30}$ and inhibits DNA methyltransferase ${ }^{23}$ and Transforming Growth Factor- $\beta 1$ (TGF $\beta 1){ }^{31}$

Despite the wide range of cytotoxicity that DOX elicits, its complete mechanism of action still not fully understood and much research has been undertaken to elucidate more clearly how DOX works, its uptake and intracellular delivery and resistance of cancer cells. ${ }^{24,32-35}$ In this context, the technique of Raman spectroscopy could add additional insight, in vitro. The anthracycline structure of DOX, consisting of a conjugated anthraquinone ring structure banded to an aminoglycoside, ${ }^{25}$ renders it fluorescent and gives it a strong Raman scattering efficiency even off resonantly, (Fig. 1A). It can therefore potentially be simultaneously tracked inside cells by confocal fluorescence microscopy and Raman spectroscopy, and therefore is an ideal candidate to probe the sensitivity of the latter to not only monitor the intracellular interactions of drugs, but also the mechanisms of interaction and the progression of subsequent cellular responses.

A number of studies over the last few years have investigated either the cellular uptake and nuclear accumulation, ${ }^{36}$ cytotoxicity or the interaction of free or nanoformulations of DOX in different cancer cell lines or isolated DNA. ${ }^{34,35,37-40}$

In this study, Raman micro spectroscopy is used as a tool, complemented by parallel cytotoxicity assays and confocal fluorescence microscopy, to both monitor DOX within the cellular environment, to detect its biochemical effects and fingerprint the physiological responses in the cancer cell line, A549, a non-small cell lung adenocarcinoma. The study thus explores the capability of the technique to screen the uptake and mechanisms of interaction of chemotherapeutic agents in vitro in a truly label free manner.

\section{Materials and methods}

\section{Cell culture}

A549 human lung adenocarcinoma cells with the alveolar type II phenotype were obtained from ATTC (Manassas, VA, USA).

A549 cells were cultured in DMEM (with $2 \mathrm{mM}$ L-glutamine) with $10 \%$ foetal bovine serum (FBS) at $37{ }^{\circ} \mathrm{C}$ in a humidified atmosphere containing $5 \% \mathrm{CO}_{2}$ and cells were split every two days to maintain $\sim 60 \%$ confluence.

For confocal fluorescence and Raman spectroscopic analysis, cell number was determined using a Beckman Coulter Particle Count and Size Analysis® Z2 Cell Counter. 


\section{Cytotoxicity assays}

Alamar blue $(\mathrm{AB})$ and 3-[4,5-dimethylthiazol-2-yl]-2,5-diphenyl tetrazolium bromide (MTT) assays were performed in 96 well plates and a total number of $1 \times 10^{5}$ cells were used to seed three plates $\left(4 \times 10^{3}\right.$ cells $\left.\mathrm{mL}^{-1}\right)$.

Doxorubicin hydrochloride ${ }^{\circledR}$ powder (Sigma Life Sciences, Ireland) was diluted in $1 \mathrm{~mL}$ sterile water to the required concentration. After $24 \mathrm{~h}$ incubation, plates were washed with phosphate buffered saline solution (PBS) and doxorubicin was added in a range from $0 \mu \mathrm{M}$ (as a control) to $50 \mu \mathrm{M}$.

A solution of $1.5 \mathrm{~mL}$ of $\mathrm{AB}(10 \times$ ready to use solution) and $3 \mathrm{~mL}$ of MTT stock solution $\left(2.5 \mathrm{mg} \mathrm{mL}^{-1}, 25 \mathrm{mg}\right.$ MTT/10 mL PBS) in $30 \mathrm{~mL}$ of fresh medium were prepared. AB and MTT assays were both measured with a Cytotox SpectraMax®M3 plate reader using Soft Max® Pro6.2.2 as software and data was treated using SigmaPlot 10.0. After $24 \mathrm{~h}$ incubation in DOX, plates were washed with PBS and $100 \mu \mathrm{L}$ of AB/MTT solution were added to each well. Plates were then incubated for 3 hours and $\mathrm{AB}$ fluorescence was measured before in the plate reader using $540 \mathrm{~nm}$ excitation and $595 \mathrm{~nm}$ emission. The medium was then removed, the plates were washed with PBS and $100 \mu \mathrm{L}$ of DMSO (dimethyl sulfoxide) were added in each well. MTT absorbance was read at $570 \mathrm{~nm}$. All cytotoxicity assays were made in triplicate and repeated three times.

\section{Confocal laser scanning fluorescence microscopy}

Approximately $1 \times 10^{4}$ cells were allowed to attach on uncoated glass bottom Petri dishes (MatTek Corporation, USA) for approximately two hours, after which they were covered with cell culture medium. After $24 \mathrm{~h}$ incubation, the medium was removed and samples were rinsed twice with sterile PBS, new medium containing DOX corresponding to the $\mathrm{IC}_{50}$ concentration (inhibitory concentration) which is the concentration that inhibits $50 \%$ of cells, ${ }^{41}$ was added and cells were incubated for $24 \mathrm{~h}$ more. At the end, cells were washed twice with sterile PBS, fixed in formalin $(4 \%, 15 \mathrm{mn})$ and kept in PBS for imaging. Control samples without exposure to DOX were also prepared in parallel, and incubated for $24 \mathrm{~h}$.

Confocal laser scanning fluorescence microscopic images were recorded using an inverted Zeiss LSM 510 confocal laser scanning microscope equipped with a $\times 60$ oil immersion objective. Doxorubicin fluorescence was excited with an argon ion laser at $488 \mathrm{~nm}$, and the emission was collected at $530 \mathrm{~nm}$.

\section{Raman micro spectroscopy}

Cells $\left(\sim 1 \times 10^{4} /\right.$ window $)$ were seeded and incubated on $\mathrm{CaF}_{2}$ windows (Crystan Ltd, UK) for $24 \mathrm{~h}$ for both control and exposure to DOX. Medium was then removed and samples were rinsed twice with sterile PBS and covered with DOX at the $\mathrm{IC}_{50}$ concentration. After $24 \mathrm{~h}$ incubation, cells were washed twice with sterile PBS and fixed in formalin (4\%, $15 \mathrm{~min})$.

A Horiba Jobin-Yvon LabRAM HR800 spectrometer with a $785 \mathrm{~nm}, 300 \mathrm{~mW}$ diode laser as source, Peltier cooled 16-bit CCD, 300 lines $\mathrm{mm}^{-1}$ grating and $100 \mu \mathrm{m}$ confocal hole, was used for this work. Spectra were acquired in the range from
$400 \mathrm{~cm}^{-1}$ to $1800 \mathrm{~cm}^{-1}$ using a $\times 100$ objective (LCPlanN, Olympus), in dry conditions, for $30 \mathrm{~s}$ two times, from three cell locations: cytoplasm, nucleus and nucleolus, to finally produce a data set of 30 points per cell location for each control and exposure to DOX, over a total of 60 cells.

\section{Data analysis}

Raman spectral pre-processing and analysis were performed in Matlab 2013 using algorithms developed in house. Prior to analysis, spectra were smoothed (Savitsky-Golay filter 5th order, 7 points), vector normalised, baseline corrected (fifth order polynomial) and background was subtracted using a NCLS (non-negatively constrained least squares) algorithm.

Principal components analysis (PCA) was employed as an unsupervised multivariate approach to analyse data and the effects of doxorubicin in each cell localisation. The order of the PCs denotes their importance to the dataset and PC1 describes the highest amount of variation. ${ }^{42,43}$

\section{Results and discussion}

\section{Cytotoxicity assays}

Fig. 2 shows the dose dependent cytotoxicity of DOX after $24 \mathrm{~h}$ according to the $\mathrm{AB}$ and MTT in vitro cytotoxicity assays. Viability is expressed as \% compared to control, and the error bars indicate the standard deviation of six independent replicate measurements. Both assays indicate a systematic dose dependent response. Neither of the assays indicates a complete loss of viability of the cell populations over the concentration range and exposure periods, and this viability cures were fitted with eqn $(1)^{44}$

$$
V=V_{\min }+\left(V_{\max }-V_{\min }\right) /\left(1+\left(C / \mathrm{IC}_{50}\right)^{n}\right)
$$

where $V$ is the \% viability, $V_{\min }$ is the minimum viability, $V_{\max }$ is the maximum viability, $C$ is the DOX concentration, $n$ is the Hill slope, and $\mathrm{IC}_{50}$ is the concentration which elicits $50 \%$ of the maximum response. The $\mathrm{IC}_{50}$ values were determined to

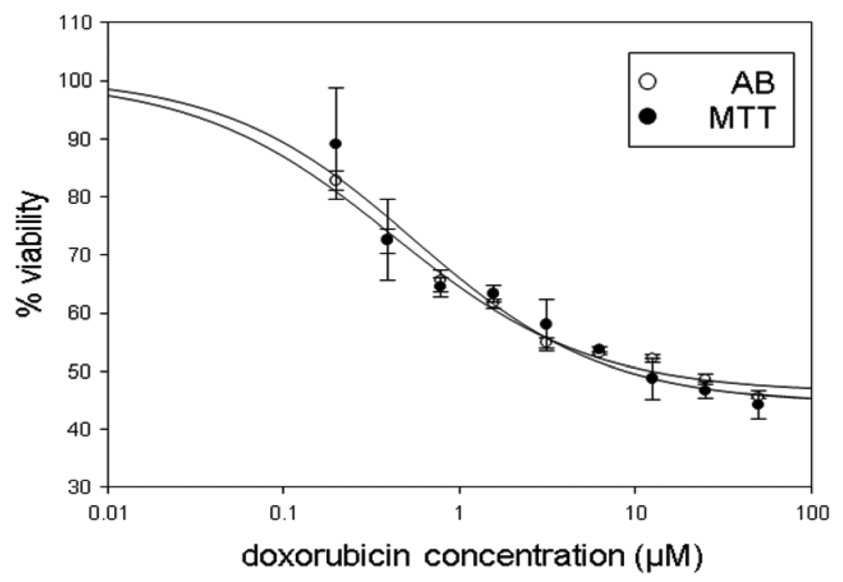

Fig. $2 \mathrm{AB}$ and MTT $24 \mathrm{~h}$ dose dependent cytotoxicity of DOX to A549. 
be $0.42 \pm 0.06 \mu \mathrm{M}$ and $0.55 \pm 0.16 \mu \mathrm{M}$ for $\mathrm{AB}$ and MTT, respectively. Although the values overlap within experimental error, any slight difference in $\mathrm{IC}_{50}$ between $\mathrm{AB}$ and $\mathrm{MTT}$ may be because the $\mathrm{AB}$ assay is a measure of overall cell metabolism whereas the MTT assay is the reflection of mitochondrial activity within the cell. Mitochondria exist within the cells in all stages of their DNA replication, and are first targeted by DOX which explains its earlier response and higher sensitivity. ${ }^{4-47}$ Since cells will be analysed after $24 \mathrm{~h}$ exposure, the $\mathrm{IC}_{50}$ determined using the MTT assay was used for the rest of the study.

\section{Confocal laser scanning fluorescence microscopy}

Confocal laser scanning fluorescence microscopy was used to confirm intracellular DOX localization and accumulation. Fig. 3 illustrates that DOX, after $24 \mathrm{~h}$ incubation, is predominantly accumulated in the cell nuclei, and no trace amounts are evident in the cytoplasm. The absence of DOX in the cytoplasm after $24 \mathrm{~h}$, confirms also that A549 cells do not present any resistance to the drug. ${ }^{33}$ It is also notable that fragmentation of nucleoli within the nucleus is observed upon DOX treatment for $24 \mathrm{~h}$, confirming that cells are going under apoptosis. $^{48}$

\section{Raman micro spectroscopy}

The Raman spectrum of DOX powder dissolved in sterile water at the concentration of $17.25 \mathrm{mM}$ (Fig. 1B) clearly shows peaks at 1445 and $1570 \mathrm{~cm}^{-1}$, related to skeletal ring vibrations, specific bands corresponding to $\mathrm{C}-\mathrm{O}, \mathrm{C}-\mathrm{O}-\mathrm{H}$ and $\mathrm{C}-\mathrm{H}$ in the region between 1200 and $1300 \mathrm{~cm}^{-1}$ and ones attributed to $\mathrm{C}-\mathrm{C}-\mathrm{O}$ and $\mathrm{C}-\mathrm{O}$ at 440 and $465 \mathrm{~cm}^{-1}$ respectively. ${ }^{4,50}$ The same peaks are clearly visible in the spectra of Fig. 4, which shows the mean spectra of the nucleolar (A), nuclear (B) and cytoplasmic (C) regions of 30 A549 cells before and after $24 \mathrm{~h}$ exposure to the MTT $\mathrm{IC}_{50}$ concentration of DOX. Grey shading in the respective spectra indicates regions of interest, which are discussed further below.

Indeed, a first observation is that, in both the nucleolar and nuclear spectra, there are discernible peaks at 440, 465, 1085, 1215 and $1245 \mathrm{~cm}^{-1}$ corresponding to DOX (indicated by the blue shaded regions). These peaks are not evident in the mean cytoplasmic spectrum, however, consistent with the absence of any fluorescence in the confocal fluorescence microscopic images of Fig. 3. Thus, the conjugated structure of DOX renders it easily visible and therefore traceable intracellularly using Raman spectroscopy, even without the application of more complex data mining methods.

Furthermore, it is obvious that many DNA peaks, for example 669, 728, 782, 830, 1095, 1340 and $1425 \mathrm{~cm}^{-1}$ in the spectra of nucleus and nucleoli of treated cells (Fig. 4A and B) are diminished compared to non-treated ones. Note that the feature at $1425 \mathrm{~cm}^{-1}$ is increased because of the contribution of the DOX peak at the same wavenumber but after DOX subtraction it can be clearly seen that this peak is diminished (see

1

A.
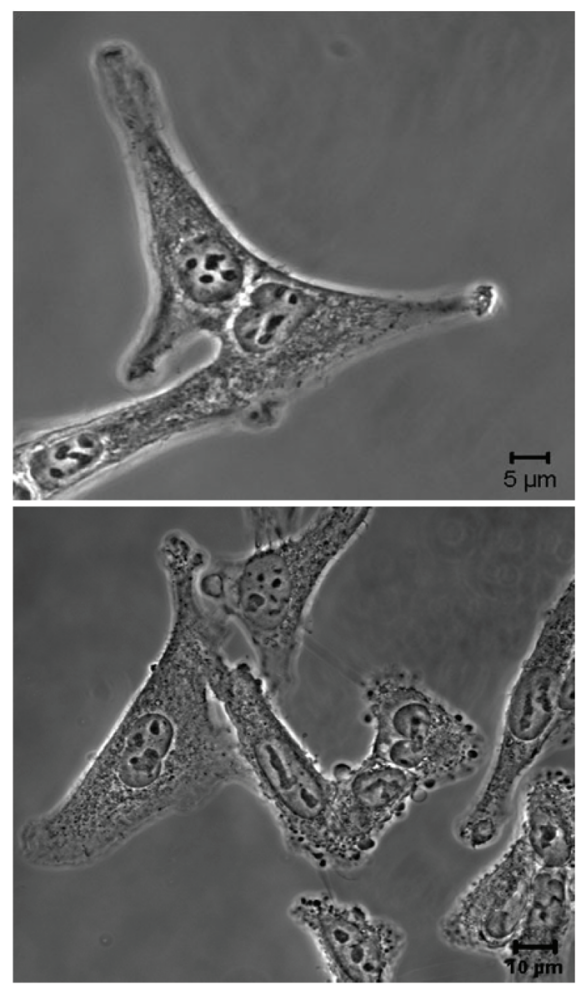

B.

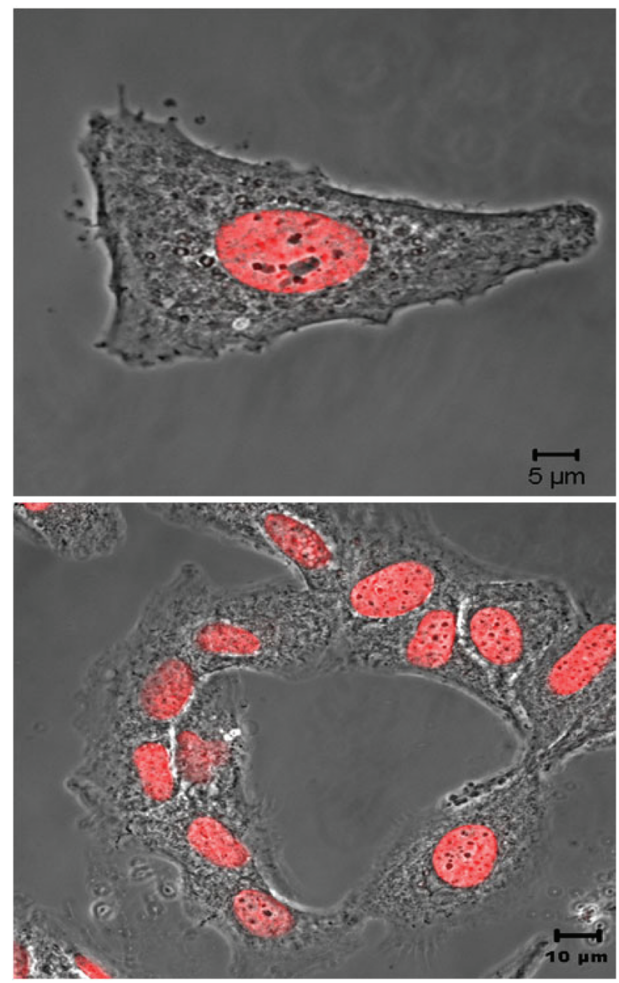

Fig. 3 In vitro confocal fluorescence images of A549 (A) control and (B) $24 \mathrm{~h}$ doxorubicin exposure. 
A. 0.08

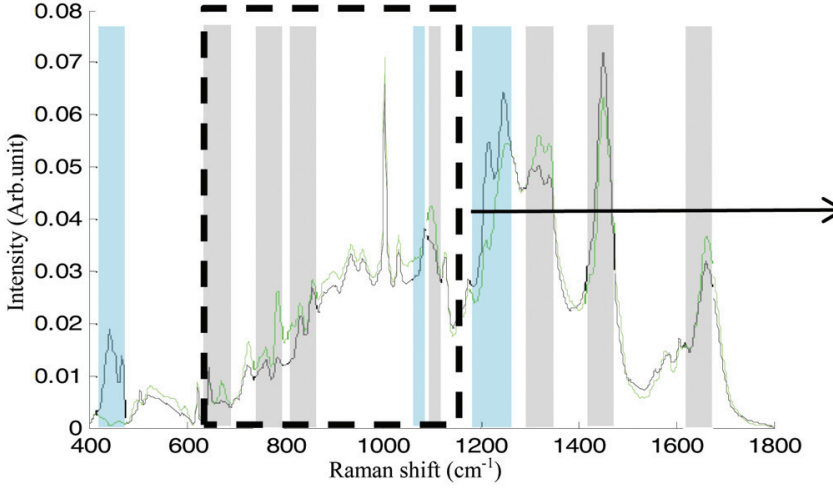

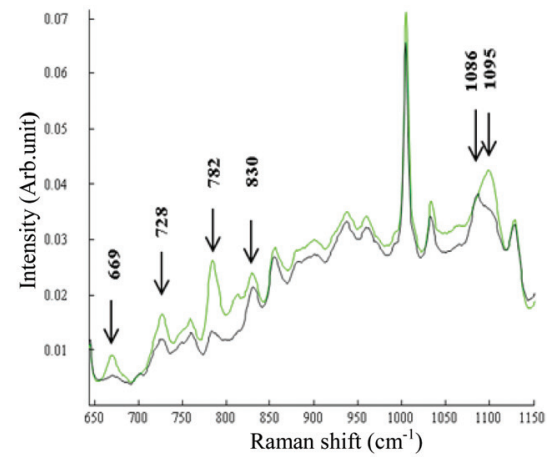

B. 0.08

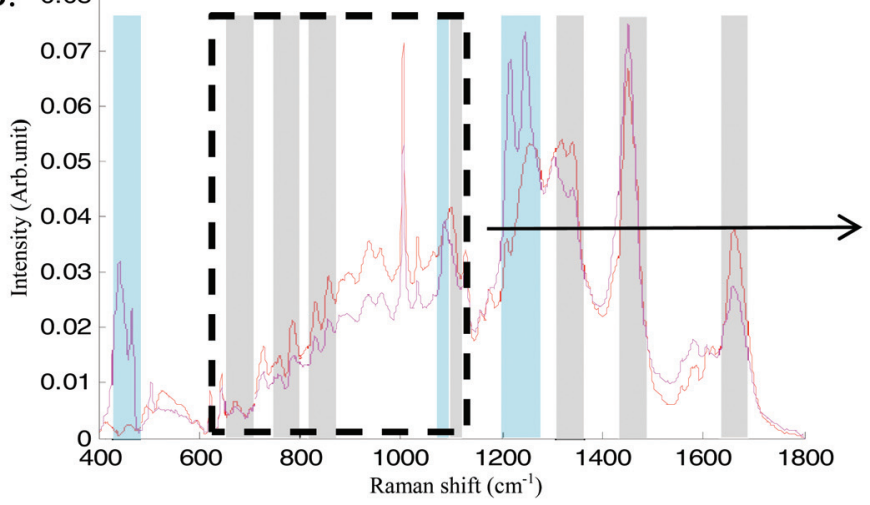

C. 0.08

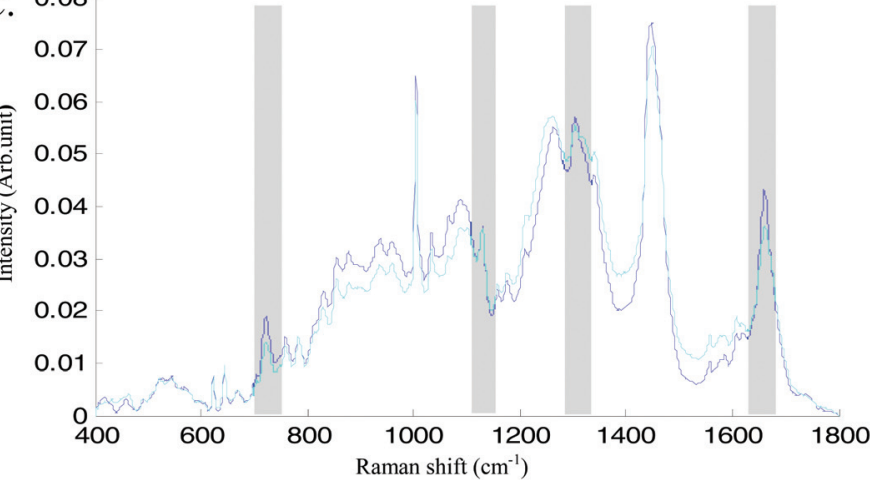

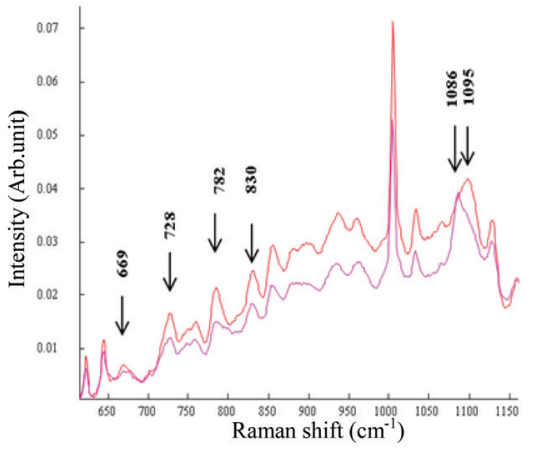

Fig. 4 Mean spectra of A549 cells (A) nucleolus (green; control, black; exposed) (B) nucleus (red; control, magenta; exposed) (C) cytoplasm (blue; control, cyan; exposed).

Fig. 8). These results are in accordance with the expected changes in cell nuclei, related to the DOX mechanism of action, by which DNA synthesis is blocked by intercalation causing changes in DNA conformation (decrease of DNA B form $)^{13}$ inducing early cell apoptosis. ${ }^{51,52}$ (Full details of cellular peak assignments are given in Table 1). A shift towards lower wavenumbers is observed for the peak at $1095 \mathrm{~cm}^{-1}$, corresponding to $\mathrm{O}-\mathrm{P}-\mathrm{O}$ stretching, (shown in the expanded section of Fig. 4A and B), which may indicate that DOX is also able to bind to DNA externally, although it is also influenced by the close proximity of the DOX peak at $1086 \mathrm{~cm}^{-1} .^{13}$ In addition to effects on DNA related spectral features, small decreases in protein peaks at 1005, 1320, 1578 and $1665 \mathrm{~cm}^{-1}$ are observed, relative to those of control (further confirmed in the PCA in Fig. 8). The decrease in intensity of DNA and protein features is consistent with the onset of apoptosis, which in turn is consistent with a DOX mechanism of action by induction of cell apoptosis, consisting of programmed and intrinsic cell death, DNA fragmentation, membrane blebbing and consequently interrupted cancer cell growth. ${ }^{48,53,54}$

In the case of the cytoplasm, a similar spectrum is obtained before and after exposure to DOX, although subtle changes of some of the spectral features are apparent (indicated by grey shaded regions in Fig. 4C), such as a decrease in the $720 \mathrm{~cm}^{-1}$ 
Table 1 Raman bands observed in spectra of the nucleolus, nucleus and cytoplasm ${ }^{5,13,53-56}$

Raman shift

$\left(\mathrm{cm}^{-1}\right)$

Assignment

669

720 and 1158

728

765

855

782

$784 \quad 795$

813

828_830

847

881

936

1005

1047

1095

1176

1246

1252

1270

1300

1303

1340, 1425 and

1578

1320,1450

1578

1661

1665
Thymine and guanine

$\mathrm{C}-\mathrm{C}-\mathrm{N}+$ symmetric stretching in

phosphatidylcholine

Adenine

Tryptophan ring

Tyrosine vibration

Uracil, cytosine and thymine

Cytosine and thymine, DNA backbone $\mathrm{O}-\mathrm{P}-\mathrm{O}$

stretching

RNA O-P-O phosphodiester bond, DNA A form

$\mathrm{O}-\mathrm{P}-\mathrm{O}$ asymmetric stretching, DNA B form

Ribose phosphate

Deoxyribose ring breathing

C-C protein skeleton stretching, $\alpha$ helix

Phenylalanine

RNA P-O stretch, sugar phosphate $-\mathrm{C}-\mathrm{O}-$

stretching

DNA $\mathrm{PO}_{2}{ }^{-}$symmetric stretching

Tyrosine and phenylalanine

Adenine

RNA uracil and cytosine ring stretching

RNA cytosine and adenine ring stretching

Lipids $\mathrm{C}-\mathrm{H}$ vibrations

Adenine and guanine

$\mathrm{CH}_{2}$ deformation

Proteins

Lipids $\mathrm{C}=\mathrm{C}$ stretching

Amide I
Amide III peak and a discrete increase in that at $1158 \mathrm{~cm}^{-1}$, both corresponding to phosphatidyl choline, one of the major cellular membrane constituents. A notable decrease is also apparent in the features at 1303 and $1665 \mathrm{~cm}^{-1}$. These small decreases in lipid and protein peaks can be explained by the fact that, although apoptotic cells exhibit major changes in the structure of DNA, cytoplasmic biochemistry and cell volume, the cellular membrane and plasma can remain almost intact for more prolonged periods. The small increase in the feature at $1158 \mathrm{~cm}^{-1}$ may derive from the initial production of membrane vesicles synthetized by cells as a way to remove waste and toxins by exocytosis. As this synthesis starts at a later time, no substantial increase in lipid constituents is observed at this stage. ${ }^{45,54}$

Although some spectral changes resulting from DOX exposure are discernible by eye, a more detailed picture is elucidated through multivariate analysis. PCA is therefore employed to analyse in more detail the effects of DOX exposure on the spectral profiles of the subcellular regions and, for this, control and exposed cells were compared and analysed, after which the raw spectrum of DOX was subtracted using NCLS and the spectra obtained were compared to those of control. Figures representing the differentiation of the different spectra by PCA according to the corresponding PCs were plotted and, for clarity, the loadings are off set, the dashed horizontal line in all cases indicating zero loading. As an illustration, Fig. 5 shows (A) PCA of control and (B) exposed and control A549 cells. For control A549 cells, there is a clear differentiation between the nuclear (including nucleolar) region and the cytoplasm by PC1 and, according to the loading, the discriminant peaks correspond predominantly to DNA and lipids. There is no discrimination of the nuclear/nucleoli regions according to PC2, which is an indication of the intrinsic point to point spectral variability.

PCA of both exposed and control cells (Fig. 5B), shows a separation between control cells (negative) and DOX exposed cells (positive) according to PC1 and the corresponding loading is dominated by features of the pure DOX spectrum (Fig. 6). Notice also that there is a discrimination between the nuclear region and the cytoplasm for both exposed and nonexposed cells according to PC2 and the corresponding loading 2 exhibits the same peaks as the loading of PC1 for PCA control cells only (Fig. 5A), namely those at 1300 and $1440 \mathrm{~cm}^{-1}$ for lipids, 795 and $1095 \mathrm{~cm}^{-1}$ for DNA.

To further elucidate the differences between exposed and control cells and to better understand the effects of DOX exposure on the spectral profiles of the different subcellular regions, PCA was employed for each cell compartment separately.

Significant discrimination can be seen between the spectra of each subcellular region of control and exposed cells, whose origin is represented by the loadings of PC1. In the case of both the nucleolar and nuclear regions (Fig. 7A and B), the discriminating peaks correspond to DOX (440, 465, 1215 and $1245 \mathrm{~cm}^{-1}$ ), whereas for the cytoplasm (Fig. 7C) there are no DOX features evident and the only difference is a decrease in protein and lipid features $\left(1303,1450\right.$ and $\left.1665 \mathrm{~cm}^{-1}\right)$.

In addition to prominent DOX peaks, in the loadings of PC1 for the nucleolar and nuclear regions of exposed and control cells, there are a number of smaller discriminants peaks which may provide further indications of the mode of interaction. In order, to better visualise these peaks, the spectrum of raw DOX powder in aqueous solution, was subtracted using NCLS, and the resultant spectra were again subjected to PCA. (Fig. 8)

As seen in Fig. 8A and B, the loading of PC1 for the nucleolar and nuclear spectra of exposed (DOX subtracted) and control cells show dominant negative discriminants peaks at $1005,1320,1450,1578$ and $1665 \mathrm{~cm}^{-1}$, corresponding to protein and lipids. As discussed further below, in relation to Fig. 9, the PC1 of the nucleolar spectra (Fig. 8A) also shows strong contributions for RNA, at $\sim 782$ and $847 \mathrm{~cm}^{-1}$. Although they sit on a positive background, negatives bands at 830,881 and $1095 \mathrm{~cm}^{-1}$ and a positive one at $813 \mathrm{~cm}^{-1}$ are evident in the PC1 of the nuclear spectra, indicating a conformational changes (B-form DNA into A-form) ${ }^{13,53}$ caused by the DOX intercalation. Changes in features at 1340,782 and $728 \mathrm{~cm}^{-1}$ are also related to DNA, which again is consistent with the intercalative mechanism of DOX, inducing a cell apoptosis. Notably, the DNA feature at $1425 \mathrm{~cm}^{-1}$, obscured in Fig. 4 by the proximity of the DOX peak also features prominently. 

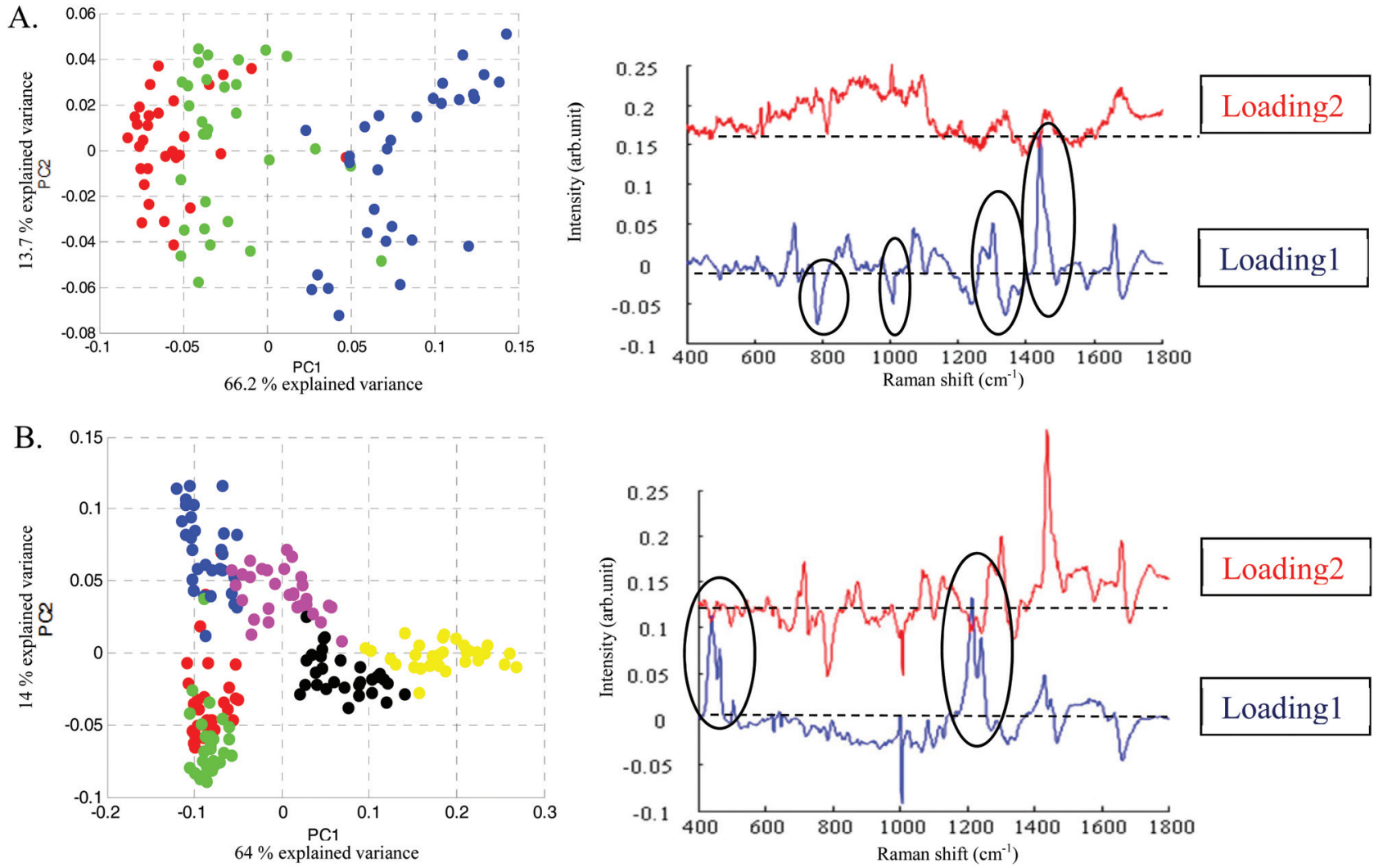

Fig. 5 (A) PCA of A549 cytoplasm, nucleus and nucleolus control (non-exposed) cells (B) PCA A549 cytoplasm, nucleus and nucleolus for both exposed and control cells. Cytoplasm @, nuclear $\bullet$ and nucleolar $\bullet$ non-exposed cell. Cytoplasm $\bullet$, nuclear and nucleolar $\bullet$ exposed cell.

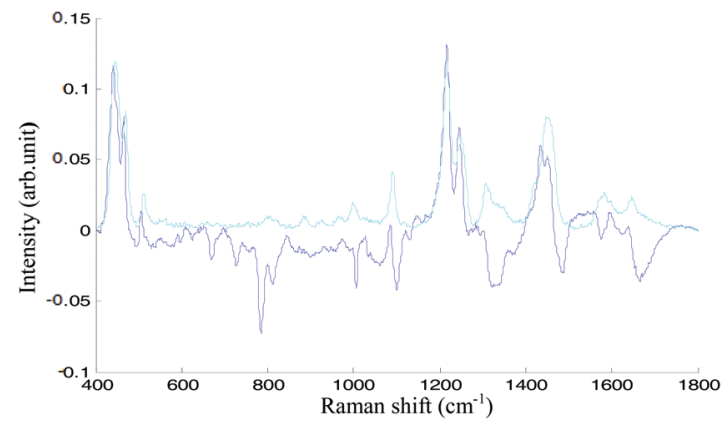

Fig. 6 Loading of PC1 (PCA of control cells vs. exposed) in blue and doxorubicin spectrum in cyan.
In addition, there is a discernible increase of the amide III peaks at $1245 \mathrm{~cm}^{-1}$ (positive peak in loading 1 ) which may be explained by the initial mobilisation of a protein group to the intercalation site to prevent DNA repair.

To better elucidate any differences in the interaction of DOX in the nucleus compared to nucleoli, PCA of only nuclear and nucleolar regions was carried out for cells exposed to DOX then after DOX subtraction and compared to PCA of control cells.
Fig. 9A clearly shows differentiation between control nuclear and nucleolar regions. The loading of PC1 presents positive discriminant peaks corresponding to RNA at 1300, 1270, 1047 and $847 \mathrm{~cm}^{-1}$ and negative ones at 1440 and $830,1450,1578 \mathrm{~cm}^{-1}$ attributed to DNA and lipids (Table 1), consistent with the predominance of DNA in the nuclear regions with lipids from the membrane and RNA in the nucleoli.

PCA of exposed nuclear and nucleolar regions (Fig. 9B) shows a similar differentiation between these two cellular compartments, but the loading of PC1 is dominated by spectral features of DOX. This is consistent with DOX localisation in both nucleolar and nuclear regions, but more so in the latter, indicating that DOX is rapidly absorbed in the nuclear region, intercalated into DNA, and only residual amounts are free to progress to the nucleoli.

PCA of nucleolar and nuclear regions of control cells (Fig. 9A) indicates that the differences between these two compartments, according to the loading of PC1, correspond to DNA and RNA. But in the PCA of the same two localisations after DOX exposure and subtraction (Fig. 9C), additional discriminant peaks are evident at 765, 1005, 1320, $1665 \mathrm{~cm}^{-1}$, corresponding to proteins, although the separation is not so evident. In addition to DNA depletion, there are also changes in the profile of nuclear proteins. These features are negative 

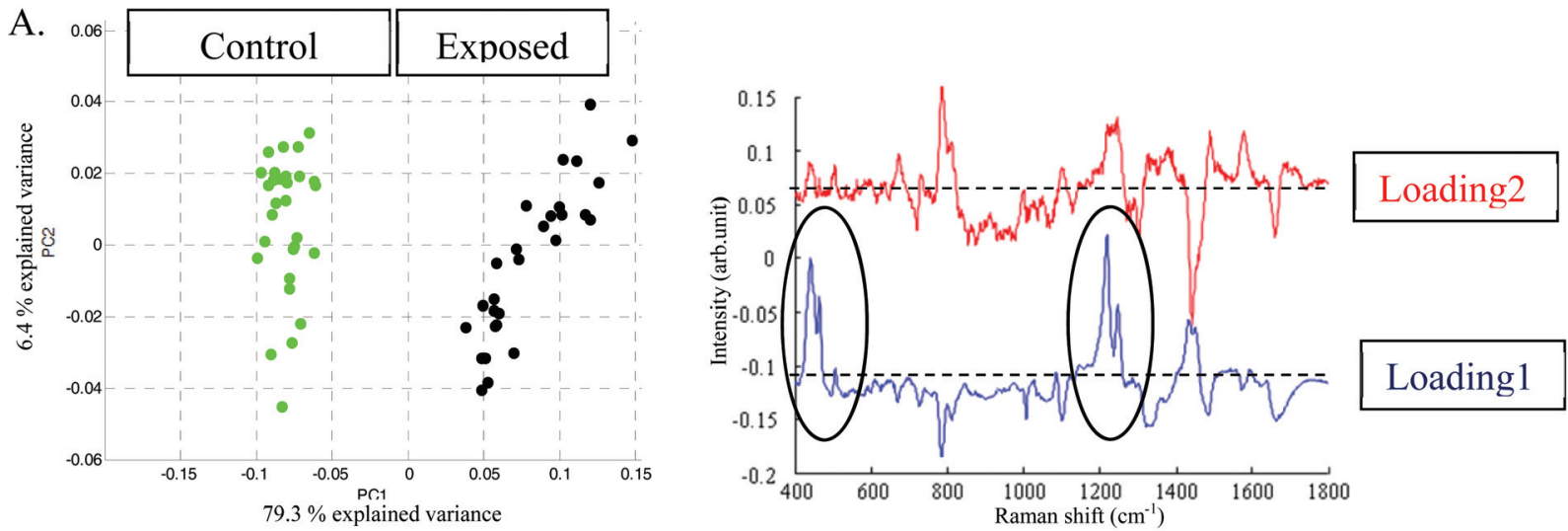

$79.3 \%$ explained variance
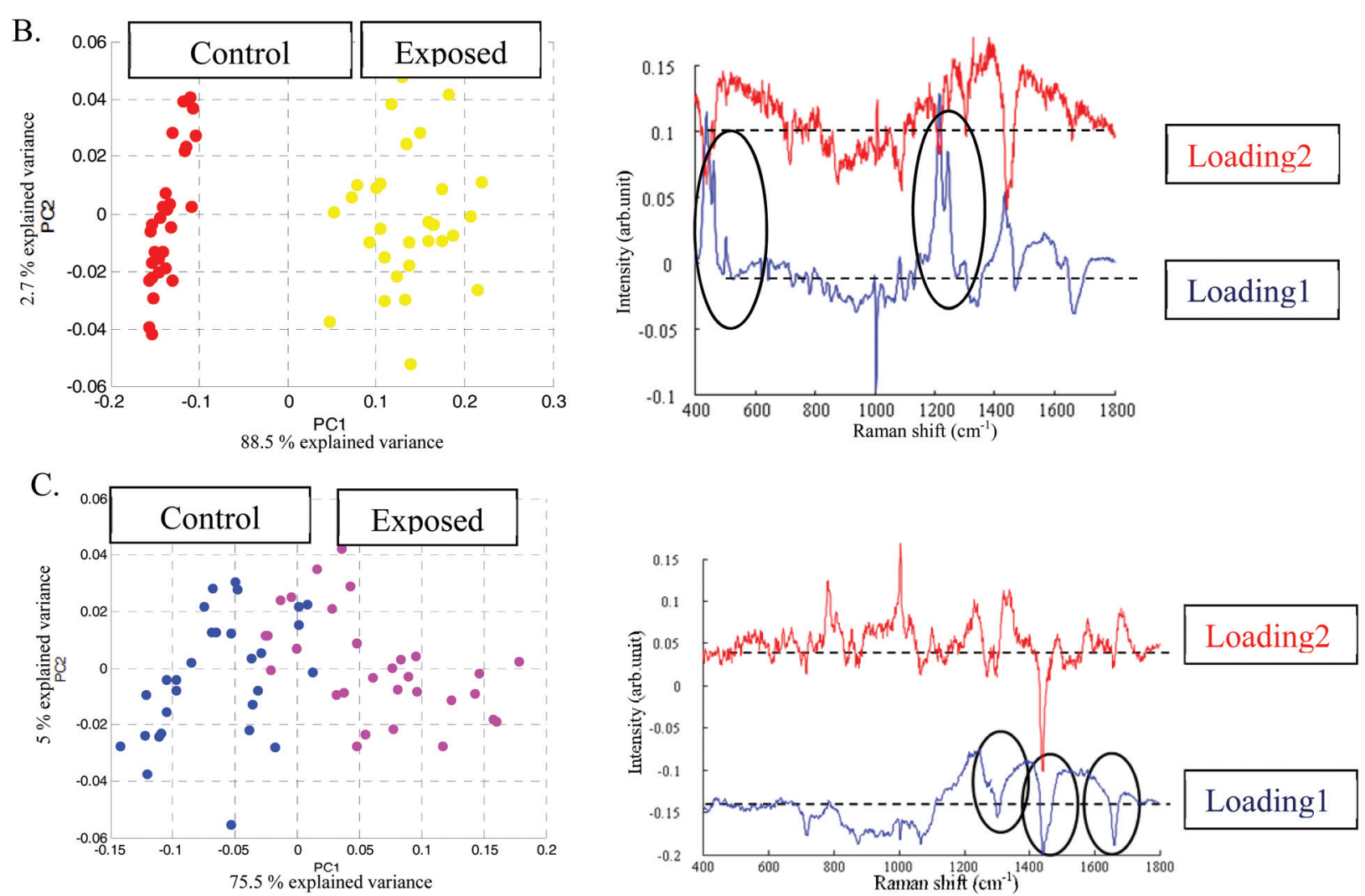

Fig. 7 PCA of exposed and control A549 cells (A) nucleolus (B) nucleus (C) cytoplasm.

with respect to $\mathrm{PC} 1$, consistent with an increased protein activity in the nucleoli. The decrease of the feature at $1450 \mathrm{~cm}^{-1}$, corresponding to lipids, may indicate that there is a denaturation of the cytoplasmic membrane surrounding the nucleus.

\section{Discussion}

anthracycline molecule, after $24 \mathrm{~h}$ exposure, is completely localised inside the cell nucleus, in which DNA is abundant, consistent with its established mechanism of action by DNA intercalation.

This nuclear localisation is manifest in the Raman nuclear and nucleolar spectra by the clear presence of DOX peaks at 465, $4451200,1300,1440$ and $1570 \mathrm{~cm}^{-1}$ and the absence of those peaks in cytoplasm spectra, and in confocal images by the red fluorescence in nucleus and nucleoli.

More in depth investigations using multivariate analysis revealed that not only DOX can be detected inside cells, but also both its biochemical effects and the physiological responses of the cells to exposure can be seen. 

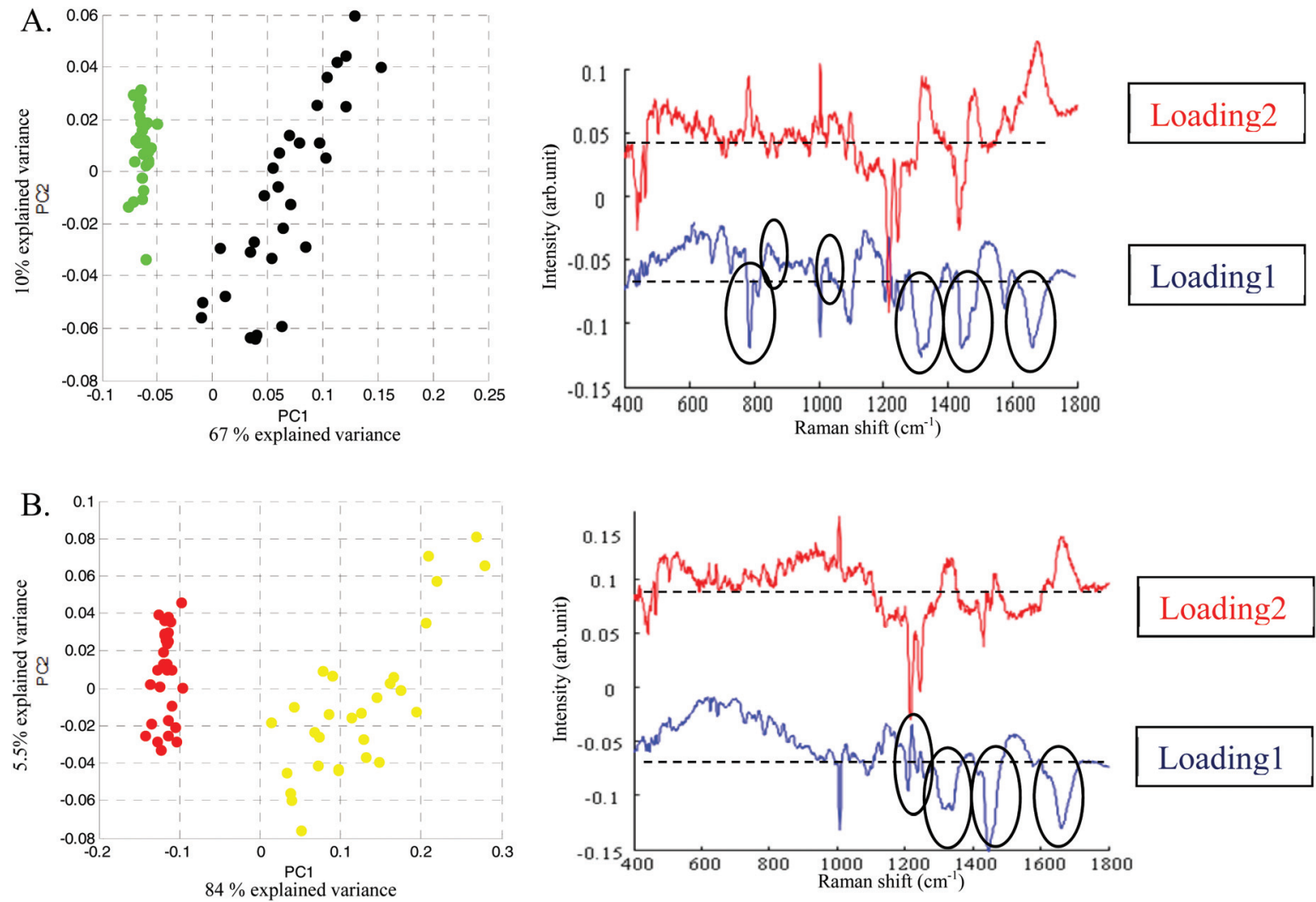

Fig. 8 A) PCA of exposed nucleolar regions after DOX subtraction (black) versus control cells (green), (B) PCA of exposed nuclear regions after DOX subtraction (yellow) versus control cells (red).

DOX is a known DNA intercalator, and the decrease in the nuclear spectral features at 669 (thymine and guanine), 728 (adenine), 782 (cytosine and thymine), 1340 and $1425 \mathrm{~cm}^{-1}$ (adenine and guanine) peaks are signatures of intercalation in the DNA duplex between two neighbouring base pairs, resulting in a decrease in the levels of $\mathrm{B}$ conformation DNA $\left(830 \mathrm{~cm}^{-1}\right) \cdot{ }^{57,58}$ Similar results were found for vincristine, a microtubule binder and mitotic inhibitor, but which was also observed to intercalate with nuclear DNA in a similar in vitro exposure of A549 cells, resulting in a diminution of thymine (669 $\left.\mathrm{cm}^{-1}\right)$, guanine $\left(1317 \mathrm{~cm}^{-1}\right)$, cytosine $\left(782 \mathrm{~cm}^{-1}\right)$ and adenine $\left(728 \mathrm{~cm}^{-1}\right)$ bands, in addition to a decrease in DNA B form $\left(827 \mathrm{~cm}^{-1}\right){ }^{13}$

A decrease in thymine $\left(669 \mathrm{~cm}^{-1}\right)$ and guanine $\left(1336 \mathrm{~cm}^{-1}\right)$ bands and to a lesser extent a reduction of the band associated with DNA conformation $\left(833 \mathrm{~cm}^{-1}\right)$, were also found with cisplatin, a well-established chemotherapeutic "groove binding" agent which binds with DNA forming inter-strand and intrastrand crosslinks at 1,2-GG and 1,3-GTG sites, leading to cell cycle arrest and apoptosis. ${ }^{11}$ For these chemotherapeutic drugs, Raman signatures of the chemical interaction with nuclear DNA have therefore been established.

Moreover, changes in nuclear proteins are also observed in the studies related to cisplatin and vincristine, as observed in the current study of DOX. However, a more notable increase in some protein peaks, amide III $\alpha$-helix $\left(1302 \mathrm{~cm}^{-1}\right)$ and $\beta$-sheet (1250-1259 $\left.\mathrm{cm}^{-1}\right), \mathrm{CH}_{2}$ deformation $\left(938 \mathrm{~cm}^{-1}\right)$, interpreted as a physiological response of the cell to the chemotherapeutic exposure, was apparent for both cisplatin and vincristine, although it should be stressed that the time exposure for the cisplatin and vincristine studies was $96 \mathrm{~h}$, as compared to the $24 \mathrm{~h}$ exposure employed in the current study, making a direct comparison of the responses impossible.

Comparing the spectral changes in exposed nucleoli to those of nucleus, it is clear that the dominant interaction with DNA occurs in the nucleus, as expected. However, the spectral changes in the nucleoli, associated with increased protein activity may provide additional insight into the early stage cellular response to toxic insult in which the cell nucleoli have been proposed to play a central role. ${ }^{59}$

In the case of the cytoplasm, distinct decreases in spectral features associated with lipids and proteins peaks are observed after DOX exposure, consistent with an apoptotic cell death mechanism, along with an increase of phosphatidyl choline, a marker of a vesicle membrane synthesis as a means to remove the cytotoxic agent by exocytosis. These results are different from those obtained for cisplatin, exposure to which results in a conformational change in cytoplasmic protein, resulting from the binding of cisplatin, along with a modification in lipids as a direct chemical effect (disintegration of lipids) and 

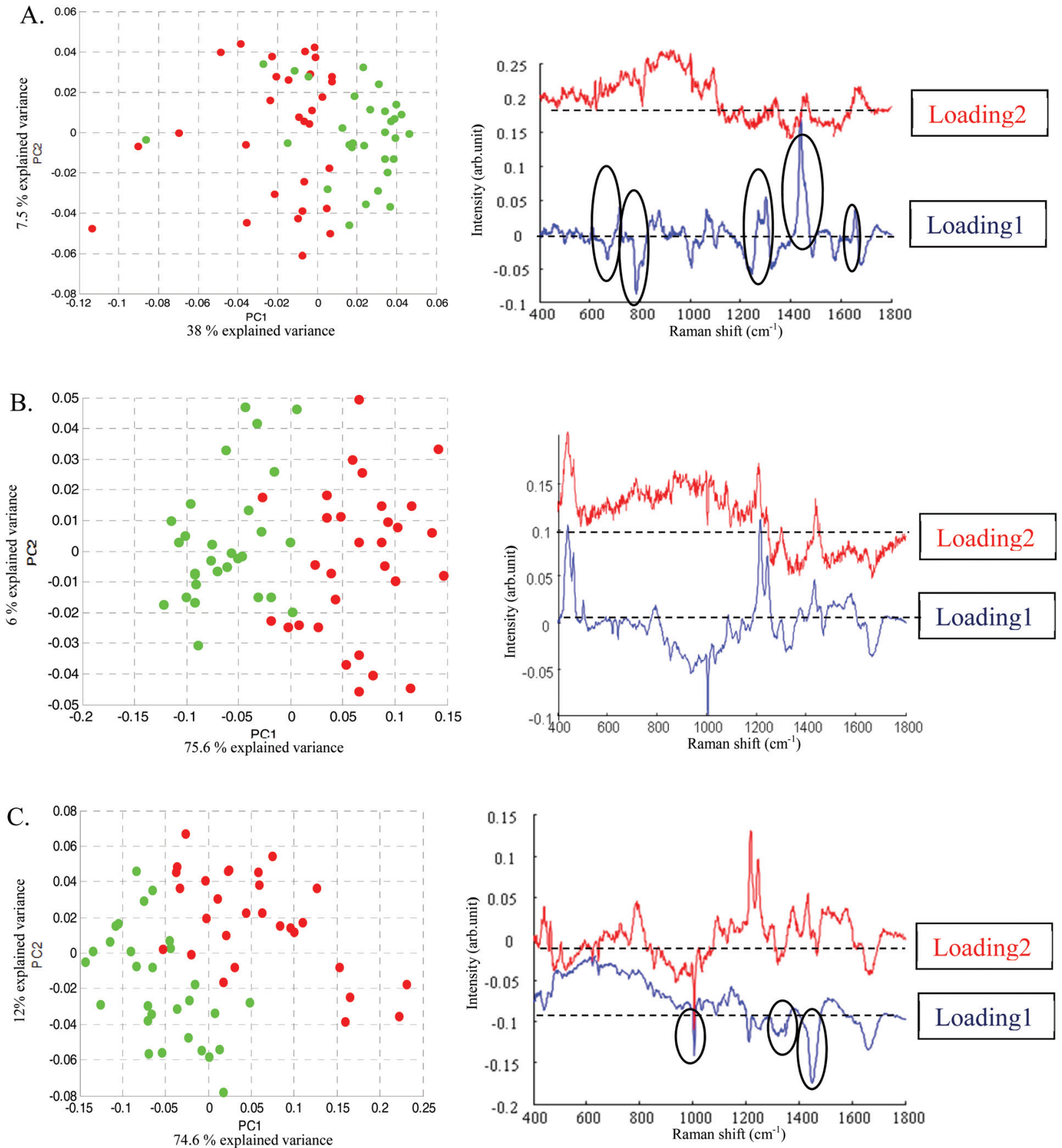

Fig. 9 PCA of nucleolar (green) and nuclear (red) regions (A) control (B) after DOX exposure (C) after DOX subtraction.

physiological response (decrease in lipids due to the reduction of cell viability).

In summary, distinct Raman spectroscopic markers of chemotherapeutic agents which interact with nuclear DNA can be established which can be used to help elucidate the mode of action of the drug. Changes in nuclear protein features can give indications of early cellular responses to the toxic insult. Raman markers for cytoplasmic biochemical effects are also evident, including decrease in both proteins and lipids, and subtle differences in the responses to exposure to different chemical agents can shed further light on the mechanisms of cellular response.

\section{Conclusion}

This study further demonstrates the potential of Raman spectroscopy as a truly label free, in vitro screening tool to monitor the interaction of molecular chemotherapeutic agents on a cellular level. In confocal microscopic mode, the technique offers 


\section{References}

1 H. J. Byrne, M. Baranska, G. J. Puppels, N. Stone, B. Wood, K. M. Gough, P. Lasch, P. Heraud, J. Sule-Suso and G. D. Sockalingum, Analyst, 2015.

2 A. Rae, R. Stosch, P. Klapetek, A. R. Hight Walker and D. Roy, Methods, 2014, 68, 338-347.

3 J. W. Chan, D. S. Taylor, T. Zwerdling, S. M. Lane, K. Ihara and T. Huser, Biophys. J., 2006, 90, 648-656.

4 P. Crow, B. Barrass, C. Kendall, M. Hart-Prieto, M. Wright, R. Persad and N. Stone, Br. J. Cancer, 2005, 92, 2166-2170.

5 I. Notingher, S. Verrier, H. Romanska, A. E. Bishop, J. M. Polak and L. L. Hench, Spectroscopy-an International Journal, 2002, 16, 43-51.

6 N. Uzunbajakava, A. Lenferink, Y. Kraan, E. Volokhina, G. Vrensen, J. Greve and C. Otto, Biophys. J., 2003, 84, 3968-3981.

7 K. C. Gordon and C. M. McGoverin, Int. J. Pharm., 2011, 417, 151-162.

8 Q. Tu and C. Chang, Nanomedicine, 2012, 8, 545-558.

9 R. S. Das and Y. K. Agrawal, Vib. Spectrosc., 2011, 57, 163176.
10 C. Kallaway, L. M. Almond, H. Barr, J. Wood, J. Hutchings, C. Kendall and N. Stone, Photodiagn. Photodyn. Ther., 2013, 10, 207-219.

11 H. Nawaz, F. Bonnier, P. Knief, O. Howe, F. M. Lyng, A. D. Meade and H. J. Byrne, Analyst, 2010, 135, 30703076.

12 H. Nawaz, F. Bonnier, A. D. Meade, F. M. Lyng and H. J. Byrne, Analyst, 2011, 136, 2450-2463.

13 H. Nawaz, A. Garcia, A. D. Meade, F. M. Lyng and H. J. Byrne, Analyst, 2013, 138, 6177-6184.

14 M. E. Keating, H. Nawaz, F. Bonnier and H. J. Byrne, Analyst, 2015.

15 S. F. El-Mashtoly, D. Petersen, H. K. Yosef, A. Mosig, A. Reinacher-Schick, C. Kotting and K. Gerwert, Analyst, 2014, 139, 1155-1161.

16 A. V. Feofanov, A. I. Grichine, L. A. Shitova, T. A. Karmakova, R. I. Yakubovskaya, M. Egret-Charlier and P. Vigny, Biophys. J., 2000, 78, 499-512.

17 K. Bräutigam, T. Bocklitz, A. Silge, C. Dierker, R. Ossig, J. Schnekenburger, D. Cialla, P. Rösch and J. Popp, J. Mol. Struct., 2014, 1073, 44-50.

18 J. Dorney, F. Bonnier, A. Garcia, A. Casey, G. Chambers and H. J. Byrne, Analyst, 2012, 137, 1111-1119.

19 L. Ahlinder, B. Ekstrand-Hammarström, P. Geladi and L. Österlund, Biophys. J., 2013, 105, 310-319.

20 A. S. Thakor, R. Paulmurugan, P. Kempen, C. Zavaleta, R. Sinclair, T. F. Massoud and S. S. Gambhir, Small, 2011, 7, 126-136.

21 A. Casey, E. Herzog, F. M. Lyng, H. J. Byrne, G. Chambers and M. Davoren, Toxicol. Lett., 2008, 179, 78-84.

22 P. Knief, C. Clarke, E. Herzog, M. Davoren, F. M. Lyng, A. D. Meade and H. J. Byrne, Analyst, 2009, 134, 1182-1191.

23 T. Yokochi and K. D. Robertson, Mol. Pharmacol., 2004, 66, 1415-1420.

24 L. H. Hurley, Nat. Rev. Cancer, 2002, 2, 188-200.

25 S. M. Cutts, A. Nudelman, A. Rephaeli and D. R. Phillips, IUBMB Life, 2005, 57, 73-81.

26 F. Yang, S. S. Teves, C. J. Kemp and S. Henikoff, Biochim. Biophys. Acta, Rev. Cancer, 2014, 1845, 84-89.

27 D. Woods and J. J. Turchi, Cancer Biol. Ther., 2013, 14, 379389.

28 S. H. Kaufmann and W. C. Earnshaw, Exp. Cell Res., 2000, 256, 42-49.

29 L. P. Swift, A. Rephaeli, A. Nudelman, D. R. Phillips and S. M. Cutts, Cancer Res., 2006, 66, 4863-4871.

30 H. Mizutani, S. Tada-Oikawa, Y. Hiraku, M. Kojima and S. Kawanishi, Life Sci., 2005, 76, 1439-1453.

31 Y. Filyak, O. Filyak, S. Souchelnytskyi and R. Stoika, Eur. J. Pharmacol., 2008, 590, 67-73.

32 T. J. Moritz, D. S. Taylor, D. M. Krol, J. Fritch and J. W. Chan, Biomed. Opt. Express, 2010, 1, 1138-1147.

33 F. Shen, S. Chu, A. K. Bence, B. Bailey, X. Xue, P. A. Erickson, M. H. Montrose, W. T. Beck and L. C. Erickson, J. Pharmacol. Exp. Ther., 2008, 324, 95-102.

34 G. Romero, Y. Qiu, R. A. Murray and S. E. Moya, Macromol. Biosci., 2013, 13, 234-241. 
35 C. J. Lee, J. S. Kang, M. S. Kim, K. P. Lee and M. S. Lee, Bull. Korean Chem. Soc., 2004, 25, 1211-1216.

36 K. Majzner, T. Wojcik, E. Szafraniec, M. Lukawska, I. Oszczapowicz, S. Chlopicki and M. Baranska, Analyst, 2015, 140, 2302-2310.

37 J. Guo, W. Cai, B. Du, M. Qian and Z. Sun, Biophys. Chem., 2009, 140, 57-61.

38 L. Xiao, M. Tang, Q. Li and A. Zhou, Anal. Methods, 2013, 5, 874-879.

39 L. Minati, V. Antonini, S. Torrengo, M. D. Serra, M. Boustta, X. Leclercq, C. Migliaresi, M. Vert and G. Speranza, Int. J. Pharm., 2012, 438, 45-52.

40 T. Wojcik, E. Buczek, K. Majzner, A. Kolodziejczyk, J. Miszczyk, P. Kaczara, W. Kwiatek, M. Baranska, M. Szymonski and S. Chlopicki, Toxicol. in Vitro, 2015, 29, 512-521.

41 R. R. Neubig, M. Spedding, T. Kenakin and A. Christopoulos, Pharmacol. Rev., 2003, 55, 597-606.

42 F. Bonnier and H. J. Byrne, Analyst, 2012, 137, 322-332.

43 F. Bonnier, P. Knief, B. Lim, A. D. Meade, J. Dorney, K. Bhattacharya, F. M. Lyng and H. J. Byrne, Analyst, 2010, 135, 3169-3177.

44 J. W. Black and P. Leff, Proc. R. Soc. London, B, 1983, 220, 141-162.

45 C. A. Owen, J. Selvakumaran, I. Notingher, G. Jell, L. L. Hench and M. M. Stevens, J. Cell Biochem., 2006, 99, 178-186.

46 M. A. Maher, P. C. Naha, S. P. Mukherjee and H. J. Byrne, Toxicol. in Vitro, 2014, 28, 1449-1460.
47 S. P. Mukherjee, M. Davoren and H. J. Byrne, Toxicol. in 1 Vitro, 2010, 24, 169-177.

48 M. W. Nasser, J. Datta, G. Nuovo, H. Kutay, T. Motiwala, S. Majumder, B. Wang, S. Suster, S. T. Jacob and K. Ghoshal, J. Biol. Chem., 2008, 283, 33394-33405.

49 C. Eliasson, A. Loren, K. V. Murty, M. Josefson, M. Kall, J. Abrahamsson and K. Abrahamsson, Spectrochim. Acta, Part A, 2001, 57, 1907-1915.

50 N. Strekal, A. German, G. Gachko, A. Maskevich and S. Maskevich, J. Mol. Struct., 2001, 563-564, 183191.

51 E. Brauchle, S. Thude, S. Y. Brucker and K. SchenkeLayland, Sci. Rep., 2014, 4.

52 H. H. Lin, Y. C. Li, C. H. Chang, C. Liu, A. L. Yu and C. H. Chen, Anal. Chem., 2012, 84, 113-120.

53 H. Yao, Z. Tao, M. Ai, L. Peng, G. Wang, B. He and Y.-q. Li, Vib. Spectrosc., 2009, 50, 193-197.

54 I. Notingher, C. Green, C. Dyer, E. Perkins, N. Hopkins, C. Lindsay and L. L. Hench, J. R. Soc. Interface, 2004, 1, 7990.

55 I. Notingher, Sensors, 2007, 7, 1343-1358.

56 Z. Movasaghi, S. Rehman and I. U. Rehman, Appl. Spectrosc. Rev., 2007, 42, 493-541.

57 D. Agudelo, P. Bourassa, G. Bérubé and H.-A. Tajmir-Riahi, 25 Int. J. Biol. Macromol., 2014, 66, 144-150.

58 H. Lei, X. Wang and C. Wu, J. Mol. Graphics Modell., 2012, 38, 279-289.

59 M. Horky, V. Kotala, M. Anton and J. Wesierska-Gadek, Ann. N. Y. Acad. Sci., 2002, 973, 258-264.

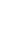

